\title{
Determinan Pola Konsumsi Makanan Berisiko pada Ibu di Kecamatan Mataram dan Gunungsari, Nusa Tenggara Barat
}

\section{Determinants of Risky Food Consumption Patterns in Mothers in Mataram and Gunungsari Districts, West Nusa Tenggara}

\author{
Luh Putu Prema Wadhani ${ }^{1 *}$, Nani Ratnaningsih²
}

\begin{abstract}
ABSTRAK
Latar Belakang: Permasalahan konsumsi pangan yang tidak sehat saat ini menjadi prioritas utama yang perlu diperhatikan. Kemajuan dan perkembangan teknologi saat ini memberikan dampak pada perubahan pola konsumsi pada masyarakat perkotaan maupun pedesaan. Konsumsi pangan yang terjadi pada setiap indivdu dipengaruhi oleh berbagai faktor baik secara internal maupun eksternal.

Tujuan: Penelitian ini bertujuan untuk mengetahui faktor determinan pola konsumsi makanan berisiko pada ibu di Kecamatan Mataram dan Gunungsari, Nusa Tenggara Barat.

Metode: Penelitian ini merupakan penelitian asosiatif dengan studi cross sectional pada bulan Januari - februari 2020. Sampel dalam penelitian ini yaitu seorang ibu yang berada di Kecamatan gunungsari dan Mataram, Nusa Tenggara Barat yang diambil dengan teknik proportional random sampling sebanyak 110 sampel. Pengumpulan data determinan pola konsumsi makanan berisiko yang terdiri dari usia, pekerjaan, pendapatan, pendidikan dan pengetahuan dikumpulkan dengan menggunakan kuesioner dan data pola konsumsi makanan berisikoi dikumpulkan dengan menggunakan lembar food frequency (SQ-FFQ). Data dalam penelitian ini dianalisis dengan menggunakan analisis regresi logistik.

Hasil: Sebanyak 75,5\% ibu berusia $30-49$ tahun, $69,9 \%$ ibu tidak bekerja, $61,8 \%$ dengan pendapatan $<$ Rp. 1.500.000/bulan, $41,8 \%$ dengan pendidikan menengah, $77,3 \%$ ibu dengan yang baik dan $74,5 \%$ ibu dengan pola konsumsi makanan berisiko sering. Tidak terdapat pengaruh pekerjaan $(p=0,824, O R=1,373)$, pendapatan $(p=0,931, O R=1,374)$ dan pendidikan $(p=0,585$, $O R=1,048)$ terhadap pola konsumsi makanan berisiko. Terdapat pengaruh usia $(p=0,001, O R=0,996)$ dan pengetahuan $(p=$ $0,019, \mathrm{OR}=0,880$ ) terhadap pola konsumsi makanan berisiko.

Kesimpulan: Perlunya perhatian lebih terhadap faktor yang dapat menyebabkan tingginya pola konsumsi makanan berisiko sehingga meningkatkan konsumsi makanan yang sehat.
\end{abstract}

Kata kunci: Determinan, Pola Konsumsi, Makanan Berisiko, Ibu

\section{ABSTRACT}

Background: The problem of unhealthy food consumption is currently a top priority that needs attention. Current technological advancements and developments have an impact on changing consumption patterns in urban and rural communities. Food consumption that occurs in each individual is influenced by various factors both internally and externally. Objectives: This study aims to determine factors of risky food consumption patterns among mothers in Mataram and Gunungsari District, West Nusa Tenggara.

Methods: This research was a cross sectional study conducted between January - February 2020. The sample in this research was mothers who lived in Gunungsari and Mataram Districts that had taken with a proportional random sampling of 110 samples. Data collection determinants of risky food consumption patterns consisting of age, occupation, income, education and knowledge were collected using a questionnaire and data risky food consumption patterns using food frequency. Data in this research were analyzed using logistic regression.

Results: As many 75.5\% of mothers aged 30 - 49 years, 69.9\% mothers not working, $61.8 \%$ with income $<R p .1,500,000 /$ month, $41.8 \%$ with secondary education, $77.3 \%$ mothers with good knowledge and $74.5 \%$ mothers with frequent risky food consumption patterns. There was no influence of occupation ( $p=0.824, O R=1.373)$, income $(p=0.931, O R=1.374)$ and education $(p=0.585, O R=1.048)$ with risky food consumption patterns. There is an influence of age $(p=0.001,0 R=0.996)$ and knowledge ( $p=0.019, O R=0.880$ ) with the risky food consumption patterns.

Conclusions: The need for more attention to factors that can cause high patterns of consumption of risky foods, thereby increasing the consumption of healthy foods.

Keywords: Determinants, Consumption Pattern, Risky Food, Mothers 


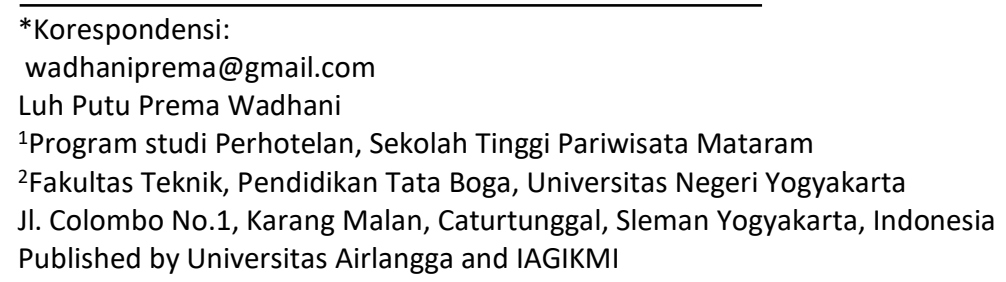

\section{PENDAHULUAN}

Masyarakat Indonesia saat ini, masih dihadapkan dengan permasalahan konsumsi pangan yang tidak tepat dan berlebihan khususnya pada konsumsi makanan berisiko seperti makanan manis, asin, berlemak, dibakar, diawetkan, instan, bumbu penyebab, minuman berkarbonasi dan berenergi. Hasil Riset Kesehatan Dasar 2018 melaporkan bahwa tingginya konsumsi makanan berisiko yang $>1$ kali/hari pada masyarakat Indoensia mencapai $61,2 \%$ pada makanan manis, 29,7\% makanan asin, 41,7\% makanan berlemak, 5,1\% makanan dibakar, 4,9\% makanan yang diawetkan, 7,8\% makanan instan, $77.6 \%$ bumbu penyebab, dan 2,2\% mengkonsumsi minuman berkarbonasi dan berenergi ${ }^{1}$. Hal ini menunjukkan bahwa tingginya angka konsumsi makanan berisiko secara berlebihan masih terjadi pada masyarakat Indonesia.

Tercapainya peningkatan derajat kesehatan masyarakat saat ini menjadi priotitas utama dalam menghasilkan sumber daya manusia yang berkualitas tinggi ${ }^{2}$. Pola konsumsi makanan yang sehat dan seimbang merupakan suatu upaya yang dapat dilakukan guna mewujudkan kesehatan pada sumber daya manusia yang berkualitas. Namun, perkembangan teknologi yang terjadi saat ini memberikan pengaruh terhadap pola konsumsi makanan berisiko yang tinggi yang memberikan dampak pada penurunan kesehatan tubuh ${ }^{3}$. Beberapa penelitian melaporkan tingginya konsumsi makanan berisiko dapat menimbulkan berbagai penyakit termasuk penyakit degeneratif, reaksi alergi serta peningkatan berat badan, sehingga adanya berbagai penyakit ini akan menurunkan sistem imun yang ada dalam tubuh secara perlahan $^{4-6}$.

Secara umum, pola konsumsi yang ada pada setiap individu dapat dipengaruhi oleh berbagai faktor, baik faktor dari dalam diri maupun faktor dari luar. Faktor dari dalam dapat berupa usia, jenis kelamin, pendidikan dan ekonomi, sedangkan faktor dari luar dapat berupa faktor lingkungan. Seorang ibu yang berada dalam rumah tangga memiliki peranan penting untuk mengatur konsumsi makanan dalam keluarga maupun dirinya sendiri ${ }^{7}$. Namun, dengan kondisi ekonomi dan pengetahuan yang beragam pada setiap orang maka menjadi suatu pemicu terjadinya perubahan perilaku konsumsi dan gaya hidup. Kemajuan dan perkembangan teknologi saat ini juga memberikan dampak pada perubahan pola konsumsi pada masyarakat perkotaan maupun pedesaan. Sebagian masyarakat perkotaan maupun pedesaan menginginkan segala sesuatu termasuk makanan diperoleh dengan cara yang praktis. Munculnya berbagai jenis makanan di sejumlah televisi, pusat perbelanjaan dan faktor lingkungan memberikan kemudahan dan mempengaruhi gaya hidup ibu yang berada di perkotaan maupun pedesaan untuk memperoleh makanan berisiko.

Pada beberapa penelitian yang telah dilakukan sebelumnya melaporkan bahwa beberapa faktor seperti jumlah anggota keluarga, harga makanan, ketersediaan makanan dan wilayah tempat tinggal berpengaruh terhadap perilaku konsumsi makanan ${ }^{8-11}$. Namun, pada penelitian ini akan diteliti lebih lanjut mengenai pengaruh faktor lainnya seperti faktor usia, pekerjaan, pendapatan, pendidikan dan pengetahuan terhadap pola konsumsi secara khusus pada makanan berisiko yang dinilai dalam bentuk skoring dan menggunakan metode pengumpulan data pola konsumsi menggunakan food frequency pada ibu yang berada di Kecamatan Mataram dan Gunungsari. Penelitian ini diharapkan mampu memberikan kontribusi mengenai faktor yang dapat berpengaruh terhadap pola konsumsi makanan berisiko. Penelitian ini juga bertujuan untuk mengetahui pengaruh usia, pekerjaan, pendapatan, pendidikan dan pengetahuan terhadap pola konsumsi makanan berisiko pada ibu. Penelitian ini diharapkan mampu memberikan pemahaman mengenai faktor faktor yang dapat mempengaruhi pola konsumsi makanan berisiko pada ibu, sehingga ibu maupun anggota keluarga lainnya Perlu memberikan perhatian lebih terhadap faktor yang dapat menyebabkan tingginya pola konsumsi makanan berisiko dan meningkatkan konsumsi makanan yang lebih sehat dalam kehisupan sehari-hari.

\section{METODE}

Penelitian ini merupakan penelitian asosiatif yang besifat Cross sectional. Penelitian ini dilakukan pada bulan Januari hingga februari 2020 di dua Kecamatan yang berada di Nusa Tenggara Barat yaitu Kecamatan Mataram dan Kecamatan Gunungsari. Pemilihan lokasi dalam penelitian ini dikarenakan pada kedua Kecamatan Mataram dan Kecamatan Gunungsari tersebut memiliki pola konsumsi makanan berisiko yang tinggi seperti makanan manis dan bumbu penyedap dengan jumlah konsumsi $>30 \%$. Selain itu, pemilihan lokasi ini diperoleh berdasarkan survey awal yang memperoleh bahwa sebagian besar masyarakat pada kecamatan Mataram dan Gunungsari cenderung mengkonsumsi makanan berisiko seperti makanan instan, makanan diawetkan, dan makanan berlemak. Populasi dalam penelitian yaitu seluruh ibu yang berada di Kecamatan Mataram dan Gunungsari sebanyak 28.755 orang. Besar sampel yang digunakan dalam penelitian ini dihitung mengunakan rumus Slovin ( $\alpha=10 \%$ ) sebanyak 110 orang sampel. Sampel dalam penelitian ini diambil dengan menggunakan teknik proportional random sampling dengan jumlah sampel sebanyak 47 di Kecamatan Mataram dan 63 sampel pada Kecamatan Gunungsari. Sampel dalam penelitian ini diambil berdasarkan inklusi yaitu seorang Ibu yang berusia $\leq 20$ tahun -49 tahun, 
seorang wanita yang memiliki minimal 1 orang anak, seorang wanita yang sudah dan atau pernah menikah dan seorang wanita yang memilik anak mulai usia bayi hingga sekolah menengah atas.

Data determinan pola konsumsi makanan berisiko terdiri dari usia, pekerjaan, pendapatan, pendidikan dan pengetahuan tentang makanan berisiko. Data usia, pekerjaan, pendapatan dan pendidikan sampel dalam penelitian ini dikumpulkan dengan teknik wawancara menggunakan kuesioner identitas. Pengetahuan konsumsi makanan berisiko selanjutnya juga dikumpulkan dengan metode wawancara dengan menggunakan kuesioner pengetahuan mengenai makanan berisiko yang terdiri dari 30 butir pertanyaan yang disusun oleh peneliti dan telah dilakukan uji validitas isi maupun konstruknya. Hasil uji validitas pada kuesioner pengetahuan ini sebesar 0,361 dan reablilitas sebesar 0,892. Data pengetahuan ibu kemudian diberi skor 1 jika jawaban benar dan 0 jika jawaban salah. Total skor pengetahuan kemudian dikategorikan dalam kategori baik, cukup dan kurang. Data pola konsumsi makanan berisiko selanjutntya dikumpulkan dengan menggunakan lembar food frequency (SQ-FFQ) selama 1 bulan terakhir terhadap konsumsi makanan berisiko yang terdiri dari makanan dan minuman manis, asin, berlemak/kolesterol, penyedap rasa, makanan dibakar, makanan yang dioleh dengan pengawet, minuman berkarbonasi dan bernergi, dan makanan instan serta mie instan. Data pola konsumsi makanan berisiko kemudian dihitung berdasarkan skor yaitu skor 50 pada konsumsi > 1 kali/hari, skor 25 dengan konsumsi 1x/hari, skor 15 dengan konsumsi 1-2 kali/minggu, skor 1 dengan konsumsi $<1$ kali/minggu, dan skor 0 dengan tidak pernah konsumsi.

Data pada penelitian ini dianalisis secara bivariat dan univariat. Analisis univariat dalam penelitian ini dilakukan untuk mendeskripsikan dan mendistribusiakan data dari usia, pekerjaan, pendapatan, pendidikan, dan pengetahuan sampel yang berada di Kota maupun Desa. Analisis bivariat dalam penelitian ini dilakukan dengan uji regresi logistic sederhana menggunakan aplikasi SPSS for windows. Penelitian ini telah mendapatkan izin penelitian dari Badan Perencanaan Pembangunan, Penelitian dan Pengembangan Daerah Pemerintah Provinsi Nusa Tenggara Barat dengan No Surat 070/004/02-BAPPEDA.

\section{HASIL DAN PEMBAHASAN}

Pengumpulan data pada penelitian ini dilakukan pada 47 ibu yang berada di Kecamatan Mataram dan 63 ibu yang berada di Kecamatan Gunungsari. Distribusi frekuensi data pada penelitian ini telah disajikan pada Tabel 1. Berdasarkan hasil analisis penelitian ini menunjukkan bahwa sebagian besar ibu berada pada rentang usia 30-49 sebanyak $83(75,5 \%)$. Hal ini terjadi karena sebagian besar usia ibu yang sesuai dengan kriteria inklusi dalam penelitian ini berada pada usia 3049. Dilihat berdasarkan status pekerjaannya, sebagian besar ibu dalam penelitian ini memiliki status pekerjaan tidak bekerja sebanyak 67 (69,9\%). Pekerjaan yang dimiliki oleh seseorang secara umum dapat mempengaruhi aktivitas pribadinya termasuk perilaku terhadap konsumsi makanan. Hasil penelitian ini sejalan dengan penelitian yang dilakukan pada ibu yang berada di Nusa Tenggara Barat dan Kabupaten Cirebon memperoleh bahwa $>60 \%$ ibu dengan status tidak bekerja ${ }^{12,13}$

Pendapatan dikategorikan sebagai suatu hasil material yang diterima oleh seseorang yang dapat digunakan sebagai alat untuk memperoleh suatu barang atau jasa. Pendapatan yang diperoleh ibu rumah tangga dalam penelitian ini ditentukan berdasarkan pendapatan dalam rumah tangga yang diterima dan dipergunakan untuk memenuhi kebutuhan dalam rumah tangga termasuk makanan. Proporsi pendapatan ibu dalam penelitian ini menunjukkan bahwa sebanyak 68 (61,8\%) ibu memiliki pendapatan rata-rata < Rp. 1.500.000/bulan dan sebagaian kecilnya memiliki pendapatan dengan rata-rata $>$ Rp. 3.500.000. Keadaan ini terjadi karena sebagian besar ibu tidak bekerja dan mengandalkan penghasilan dari kepala keluarga, sehingga pendapatan yang diperoleh dalam rumah tangga masih dalam kategori yang rendah. Hal ini terjadi karena sebagian besar ibu tidak bekerja sehingga penghasilan yang diperoleh dalam rumah tangga hanya bergantung dari anggota keluarga lainnya yang bekerja.

Dilihat berdasarkan kategori tingkat pendidikan, sebanyak $46(41,8 \%)$ ibu pada tingkat pendidikan menegah. Keadaan ini sesuai dengan Kementerian Pemberdayaan Perempuan dan Perlindungan Anak (2019) yang memperoleh bahwa capaian pendidikan perempuan Indonesia di Tahun 2018 mencapai 98,82\% pada tingkat pendidikan SMA pada laporan profil perempuan Indoensia ${ }^{14}$. Hal ini menunjukkan bahwa pendidikan pada perempuan di Indonesia sudah meningkat dari tahun sebelumnya.

Proporsi pengetahuan ibu mengenai makanan berisiko pada penelitian ini menunjukkan bahwa sebanyak 85 (77,3\%) ibu memiliki pengetahuan mengenai konsumsi makanan berisiko yang baik dan tidak terdapat pengetahuan dengan kategori yang kurang. Hasil penelitian ini sejalan dengan penelitian di Desa Buhu Kecamatan Tegal yang memperoleh sebanyak $56,1 \%$ ibu memiliki pengetahuan gizi dengan kategori yang baik ${ }^{15}$. Selain itu, hasil penelitian lainnya yang dilakukan pada ibu hamil di Kenya dan Kota Surabaya juga memperoleh bahwa $>20 \%$ ibu memiliki pengetahuan terkait gizi dengan kategori yang baik ${ }^{16,17}$. Secara umum, kurangnya pemahaman dan pengetahuan mengenai konsumsi makanan yang seimbang dan bergizi dapat menyebabkan penurunan konsumsi makanan sehat dan berdampak pada terjadinya masalah gizi dan timbulnya berbagai penyakit ${ }^{18}$. Dengan adanya informasi baru mengenai konsumsi makanan berisiko maka memberikan landasan kognitif yang baru bagi terbentuknya pengetahuan dalam pemilihan makanan yang sehat bagi tubuh. 
Tabel 1. Distribusi Frekuensi Determinan dan Pola Konsumsi Makanan Berisiko

\begin{tabular}{lcc}
\hline \multicolumn{1}{c}{ Variabel } & \multicolumn{2}{c}{ Jumlah } \\
\cline { 2 - 3 } & $\mathbf{N}$ & $\%$ \\
\hline Usia & & \\
$\leq 20$ Tahun & 7 & $6,3 \%$ \\
21-29 Tahun & 20 & $18,2 \%$ \\
30-49 Tahun & 83 & $75,5 \%$ \\
Pekerjaan & & \\
Tidak Bekerja & 67 & $69,9 \%$ \\
Bekerja & 43 & $30,1 \%$ \\
Pendapatan & & \\
<1.500.000 & 68 & $61,8 \%$ \\
1.500.000 s/d 2.500.000 & 18 & $16,4 \%$ \\
2.500.000 s/d 3.500.000 & 16 & $14,5 \%$ \\
> Rp. 3.500.000 & 8 & $7,3 \%$ \\
Pendidikan & & \\
Dasar (SD/MI) & 28 & $25,5 \%$ \\
Menengah (SMA/MA/MTs) & 46 & $41,8 \%$ \\
Tinggi (Diploma, S1, S2, S3,Prof) & 36 & $32,7 \%$ \\
Pengetahuan & & \\
Baik & 85 & $77,3 \%$ \\
Cukup & 25 & $22,7 \%$ \\
Kurang & 0 & $0 \%$ \\
Pola Konsumsi Makanan Berisiko & & \\
Sangat Sering & 12 & $10,9 \%$ \\
Sering & 82 & $74,5 \%$ \\
Jarang & 16 & $14,5 \%$ \\
\hline & &
\end{tabular}

Pola konsumsi makanan berisiko merupakan suatu tindakan yang dilakukan dalam mengkonsumsi pangan yang termasuk dalam golongan makanan berisiko dengan memperhitungkan jumlah dan jenis yang dapat diukur secara kuantitatif ${ }^{19}$. Pola konsumsi makanan berisiko dalam penelitian ini terdiri dari konsumsi makanan dan minuman manis, asin, berlemak/kolesterol, penyedap rasa, makanan dibakar, makanan yang dioleh dengan pengawet, minuman berkarbonasi dan bernergi, dan makanan instan serta mie instan ${ }^{1}$. Hasil penelitian ini menunjukkan bahwa sebanyak $82(74,5 \%)$ ibu memiliki pola konsumsi makanan berisiko yang sering dan sebagian kecil lainnya termasuk dalam kategori yang jarang. Hal tersebut dapat terjadi karena perkembangan berbagai pusat perbelanjaan dan tersedianya berbagai jenis dan jumlah bahan makanan berisiko pada sekitar wilayah tempat tinggal. Selain itu, kebiasaan, kesukaan dan banyaknya kegiatan responden sehingga hal tersebut menjadi penyebab tingginya frekuensi konsumsi makanan berisiko pada ibu ${ }^{11}$. Hasil penelitian ini juga sejalan dengan penelitian di Kota Semarang yang menunjukkan bahwa $95,4 \%$ wanita memiliki pola konsumsi fast food dengan kategori yang sering. Selain itu, penelitian ini juga sejalan dengan penelitian yang dilakukan pada pasien yang berada di Poliklinik
Universitas Lampung yang memperolah bahwa sebanyak $48,1 \%$ pasien dengan riwayat pola konsumsi makanan berisiko yang tinggi ${ }^{20,21}$.

Pola konsumsi makanan yang terjadi pada setiap orang dapat tumbuh dan berkembang dengan adanya proses sosialisasi dan faktor faktor yang dapat mempengaruhinya. Setiap orang memiliki pola konsumsi makanan yang berbeda beda karena dengan adanya faktor faktor yang mempengaruhinya. Faktor internal merupakan salah satu faktor determinan pada pola konsumsi ${ }^{20}$. Hasil analisis bivariat pada determinan pola konsumsi dalam penelitian ini disajikan pada Tabel 2 . Hasil penelitian ini menunjukkan bahwa terdapat pengaruh usia terhadap pola konsumsi makanan berisiko. Hasil analisis ini juga menunjukkan bahwa nilai rasio pengaruh sebesar 0,996 yang artinya semakin tinggi usia ibu memberikan peluang sebesar 0,996 kali dalam mempengaruhi pola konsumsi makanan berisiko. Setiap orang memiliki kemampuan yang berbeda-beda terhadap pemilihan konsumsi makanan yang dibentuk dalam tahapan dan siklus kehidupan maupun keluarga ${ }^{21}$. Hasil penelitian ini sebanding dengan penelitian sebelumnya yang memperolah bahwa terdapat perbedaan yang nyata pada pola konsumsi makanan pada ibu berdasarkan usia dan indeks massa tubuh ${ }^{22}$. 
Tabel 2. Determinan Pola Konsumsi Makanan Berisiko Pada Ibu Rumah Tangga

\begin{tabular}{|c|c|c|c|c|c|c|c|c|}
\hline \multirow{3}{*}{ Variabel } & \multicolumn{6}{|c|}{ Pola Konsumsi Makanan Berisiko } & \multirow{3}{*}{ p (Value) } & \multirow{3}{*}{$\begin{array}{c}\text { OR } \\
(95 \% \mathrm{Cl})\end{array}$} \\
\hline & \multicolumn{2}{|c|}{$\begin{array}{l}\text { Sangat } \\
\text { Sering }\end{array}$} & \multicolumn{2}{|c|}{ Sering } & \multicolumn{2}{|c|}{ Jarang } & & \\
\hline & $\mathbf{n}$ & $\%$ & n & $\%$ & $\mathbf{N}$ & $\%$ & & \\
\hline \multicolumn{9}{|l|}{ Usia } \\
\hline$\leq 20$ Tahun & 0 & 0 & 3 & 42,8 & 4 & 57,2 & \multirow{3}{*}{0,001} & \multirow{3}{*}{$0,996(0,420-2,362)$} \\
\hline $21-29$ Tahun & 4 & 16,7 & 15 & 62,5 & 5 & 20,8 & & \\
\hline $30-49$ Tahun & 8 & 10,1 & 64 & 81,0 & 7 & 8,9 & & \\
\hline \multicolumn{9}{|l|}{ Pendidikan } \\
\hline Dasar (SD/MI) & 2 & 7,2 & 22 & 78,6 & 4 & 14,2 & \multirow{3}{*}{0,586} & \multirow{3}{*}{$1,048(0,392-2,805)$} \\
\hline Menengah (SMA/MA/MTs) & 8 & 17,4 & 31 & 67,4 & 7 & 15,2 & & \\
\hline $\begin{array}{l}\text { Tinggi (Diploma, S1, S2, S3, } \\
\text { Prof) }\end{array}$ & 2 & 5,6 & 29 & 80,5 & 5 & 13,9 & & \\
\hline \multicolumn{9}{|l|}{ Pekerjaan } \\
\hline Tidak Bekerja & 8 & 11,9 & 48 & 71,6 & 11 & 16,5 & \multirow[t]{2}{*}{0,824} & \multirow[t]{2}{*}{$1,373(0,321-5,866)$} \\
\hline Bekerja & 4 & 11,2 & 27 & 75,0 & 5 & 13,8 & & \\
\hline \multicolumn{9}{|l|}{ Pendapatan } \\
\hline$<1.500 .000$ & 8 & 11,8 & 49 & 72,0 & 11 & 16,2 & \multirow{4}{*}{0,931} & \multirow{4}{*}{$1,374(0,323-5,839)$} \\
\hline $1.500 .000 \mathrm{~s} / \mathrm{d} 2.500 .000$ & 3 & 16,7 & 12 & 66,6 & 3 & 16,7 & & \\
\hline $2.500 .000 \mathrm{~s} / \mathrm{d} 3.500 .000$ & 1 & 6,2 & 14 & 87,6 & 1 & 6,2 & & \\
\hline$>$ Rp. 3.500.000 & 0 & 0 & 7 & 87,5 & 1 & 12,5 & & \\
\hline \multicolumn{9}{|l|}{ Pengetahuan } \\
\hline Baik & 7 & 8,2 & 69 & 81,2 & 9 & 10,6 & \multirow{3}{*}{0,019} & \multirow{3}{*}{$0,800(0,329-1,943)$} \\
\hline Cukup & 5 & 20,0 & 13 & 52,0 & 7 & 28,0 & & \\
\hline Kurang & 0 & 0 & 0 & 0 & 0 & 0 & & \\
\hline
\end{tabular}

Berdasarkan hasil analisis Tabel 2 diketahui bahwa sebanyak $31(67,4 \%)$ ibu dengan tingkat pendidikan menengah (SMA/MA/MTs) memiliki pola konsumsi makanan berisiko dengan kategori sering. Selain itu, hasil analisis pengaruh pendidikan terhadap pola konsumsi makanan berisiko menunjukkan bahwa tidak terdapat pengaruh pendidikan terhadap perilaku konsumsi makanan berisiko. Pendidikan ibu dalam penelitian ini memiliki nilai OR sebesar 1,048 terhadap pola konsumsi makanan berisiko yang artinya tingkat pendidikan ibu memberikan pengaruh sebanyak 1,048 kali terhadap pola konsumsi makanan berisiko. Pendidikan merupakan salah satu faktor internal yang dapat mempengaruhi pola konsumsi makanan berisiko. Pengalaman dan pembelajaran yang berlangsung dapat berlangsung dari lingkungan dan sepanjang kehidupan ${ }^{23}$. Pendidikan pada seseorang merupakan proses peningkatan yang dilakukan untuk menuju puncak optimal terkait pengetahuan, sikap dan tindakan ${ }^{23}$. Pengetahuan yang diperolah pada jenjang pendidikan memberikan pengaruh terhadap pengaruh yang penting bagi perubahan pola konsumsi makanan yang akan dipilihnya. Namun, hasil penelitian ini bertolak belakang dengan penelitian di Kota Kendari yang menunjukkan bahwa perilaku konsumsi pangan yang berasal dari ternak diperngaruhi oleh tingkat pendidikan ${ }^{8}$.

Berdasarkan hasil analisis Tabel 2. pada pengaruh pekerjaan terhadap pola konsumsi makanan berisiko menujukkan bahwa sebanyak $48(71,6 \%)$ ibu tidak bekerja memiliki pola konsumsi makanan berisiko yang sering. Hasil analisis juga diperoleh bahwa nilai $p=0,824(p>0,05)$ hal ini menujukkan bahwa tidak terdapat pengaruh pekerjaan terhadap pola konsumsi makanan berisiko dengan rasio pengaruh sebesar 1,373 yang artinya pekerjaan ibu memberikan peluang atau pengaruh sebanyak 1,373 kali terdapat pola konsumsi makanan berisiko. Selain itu, pada hasil analisis pengaruh pendapatan terhadap pola konsumsi makanan berisiko menunjukkan bahwa sebanyak $49(72,0 \%)$ ibu dengan penghasilan rata-rata $1.500 .000 \mathrm{~s} / \mathrm{d} 2.500 .000$ memiliki pola konsumsi makanan berisiko dengan kategori yang sering. Hasil analisis tersebut juga memperoleh bahwa tidak terdapat pengaruh pendapatan terhadap pola konsumsi makanan berisiko dengan nilai $p=0,931$ ( $p>0.05)$ dengan nilai OR sebesar 1,374 yang artinya penghasilan ibu dengan rata-rata $1.500 .000 \mathrm{~s} / \mathrm{d} 2.500 .000$ memberikan peluang atau pengaruh sebesar 1,374 kali dibadingkan rata rata penghasilan lainnya terhadap pola konsumsi makanan berisiko pada ibu.

Keterlibatan faktor pekerjaan dan pendapatan mempengaruhi pola konsumsi dapat berdampak pada gaya hidup yang akan dilakukannya terkait jenis makanan yang akan dikonsumsi seperti makanan berisiko. Kedudukan dan jabatan dalam pekerjaanyang dimiliki oleh setiap orang menimbulkan adanya pergeseran daya beli dan minat terhadap makanan yang akan dikonsumsinya. Hasil penelitian ini sesuai dengan penelitian pada tahun 2019 yang memperoleh bahwa pekerjaan yang dimiliki tidak berhubungan dengan perilaku kebiasaan dalam mengkonsumsi jajanan ${ }^{24}$. Selain itu, beberapa penelitian lainnya sejalan dengan hasil penelitian ini yang melaporkan bahwa faktor pendapatan tidak berhubungan signifikan terhadap perilaku konsumsi buah dan sayur serta perilaku konsumsi pangan yang 
berasal dari ternak ${ }^{8,25}$.

Berdasarkan hasil penelitian ini diketahui bahwa sebagian besar ibu tidak bekerja, dengan adanya faktor pekerjaan tersebut, maka tentunya keterlibatan faktor pendapatan juga menjadi hal yang sangat berpengaruh terhadap pola konsumsi seseorang. Kemampuan akan membeli makanan yang tidak sehat dan makanan berisiko seperti makanan manis, asin, berlemak, minuman berenergi dan berkarbonasi, makanan instan berpengawet serta tingginya konsumsi makanan dengan penggunaan bumbu penyedap maka akan meningkat ${ }^{26}$. Keadaan tidak adanya pengaruh pekerjaan, pendapatan dan pendidikan dalam penelitian ini terjadinya karena faktor pekerjaan, pendapatan dan pendidikan bukan merupakan satu satunya faktor internal yang dapat mempengaruhi pola konsumsi pada seseorang. Faktor lain yang dapat mempengaruhi pola konsumsi pada seseorang dapat berupa preferensi, gaya hidup, lingkungan, akses terhadap bahan pangan dan faktor psikologi dalam diri setiap orang ${ }^{12}$.

Pengetahuan yang dimiliki oleh setiap orang terhadap suatu makanan mamberikan pengaruh yang penting bagi perubahan gaya hidup terhadap makanan. Selain itu, pengetahuan yang dimiliki menjadikan pembenaran positif terhadap pola makan pada setiap orang sehingga dengan adanya informasi baru mengenai konsumsi makanan berisiko maka memberikan landasan kognitif yang baru bagi terbentuknya pengetahuan dalam pemilihan makanan yang sehat bagi tubuh ${ }^{26}$. Hasil penelitian ini menunjukkan bahwa terdapat pengaruh pengetahuan terhadap pola konsumsi makanan berisiko pada ibu. Hasil penelitian ini juga memperolah bahwa nilai OR sebesar 0,800 yang artinya pengetahuan yang dimiliki oleh ibu dalam penelitian ini memberikan peluang atau pengaruh sebesar 0,800 kali terhadap pola konsumsi makanan berisiko. Penelitian ini sejalan dengan penelitian pada anak sekolah dasar di Kota Manado menunjukkan bahwa pengetahuan merupakan salah satu faktor yang memiliki keterkaitan terhadap perubahan perilaku konsumsi pada anak sekolah dasar di Kota Manado ${ }^{24}$.

\section{KESIMPULAN}

Berdasarkan hasil penelitian ini maka dapat ditarik kesimpulan bahwa usia, pekerjaan, pendapatan dan pendidikan tidak berpengaruh secara signifikan terhadap pola konsumsi makanan berisiko pada ibu. Namun, terdapat pengaruh pengetahuan mengenai konsumsi makanan berisiko terhadap pola konsumsi makanan berisiko. Perlunya perhatian lebih dalam pola konsumsi makanan bersiko pada ibu, karena pola konsumsi makanan berisiko yang berlebih dengan frekuensi yang sering akan memberikan dampak pada kesehatan tubuh dalam jangka waktu yang lama seperti timbulnya berbagai penyakit degeneratif dan perubahan status gizi. Selain itu, perlu dilakukan dan ditelusuri lebih lanjut mengenai faktor internal maupun eksternal lainnya yang dapat menyebabkan tingginya pola konsumsi makanan berisiko baik pada ibu maupun berbagai kalangan usia lainnya.

\section{ACKNOWLEDGEMENT}

Pada kesempatan ini peneliti mengucapkan terimakasih yang sebesar-besarnya kepada seluruh anggota staf serta pejabat di Provinsi Nusa Tenggara Barat, khususnya di Kecamatan Mataram dan Kecamatan Gunungsari yang telah memberikan izin dalam proses pelaksanaan penelitian ini.

\section{REFERENS}

1. Kesehatan, B. P. Dan P. Hasil Utama Riskesdas 2018. (2018).

2. Akhriani, M., Fadhilah, E. \& Kurniasari, F. N. Hubungan Konsumsi Minuman Berpemanis Dengan Kejadian Kegemukan Pada Remaja Di Smp Negeri 1 Bandung. Indones. Jurnal Human Nutrition. 2, 48-59 (2016).

3. Ronitawati, P., Setiawan, B. \& Sinaga, T. Analisis Konsumsi Buah Dan Sayur Pada Model Sistem Penyelenggaraan Makanan Di Sekolah Dasar. Media Kesehatan Masyarakat Indonesia. 12, 3540 (2016).

4. Djohar, M. A., Timbowo, S. M. \& Mentang, F. Tingkat Kesukaan Panelis Terhadap Penyedap Rasa Alami Hasil Samping Per. Media Teknol. Has. Perikan. 6, 37-41 (2018).

5. Septianggi, F. N., Mulyati, T. \& K, H. S. Hubungan Asupan Lemak Dan Asupan Kolesterol Dengan Kadar Kolesterol Total Pada Penderita Jantung Koroner Rawat Jalan Di Rsud Tugurejo Semarang. Jurnal Gizi Univ. Muhammadiyah Semarang 2, 13-20 (2013).

6. Kazmi, Z., Fatima, I., Perveen, S. \& Malik, S. S. Monosodium Glutamate: Review On Clinical Reports. Int. J. Food Prop. 20, 1807-1815 (2017).

7. Saleh, A., Nurachmah, E., Hadju, V., As'ad, S. \& Hamid, S. K. Pengaruh Pemberdayaan Ibu Dalam Perawatan Bayi Melalui Pendekatan Modelling. Media Kesehatan Masyarakat Indonesia. 13, 107 (2017).

8. Hadini, H. A., Ba'a, L. O., Aka, R. \& Syamsuddin. Pengaruh Faktor Sosial Ekonomi Terhadap Konsumsi Pangan Asal Ternak Di Kota Kendari. J. Jitro 4, 62-71 (2017).

9. Stankevich, A. Explaining The Consumer Decision-Making Process: Critical Literature Review. J. Int. Bus. Res. Mark. 2, 7-14 (2017).

10. Chaudhary, J., Jora, R., Sharma, P., Gehlot, R. \& Sushil. A Study Of Iron And Zinc Deficiency On Short Term Memory In Children \& Effect Of Their Supplementation. Asian Journal Biomed Pharmachy Science. 5, 12-15 (2015).

11. Ramadanus, Tarumun, S. \& Elinur. Faktor-Faktor Yang Mempengaruhi Konsumsi Pangan Sumber Karbohidrat Di Provinsi Sumatera Barat. J. Din. Pertan. Xxviii, 121-130 (2013).

12. Mawaddah, S., Barlianto, W. \& Nurdiana. Indonesian Journal Of Human Nutrition. Indones. J. Hum. Nutr. 5, 85-95 (2018).

13. Yuniar, W. P., Khomsan, A., Dewi, M., Ekawidyani, K. R. \& Mauludyani, A. V. R. Hubungan Antara Perilaku Gizi Dan Perilaku 
Hidup Bersih Dan Sehat (Phbs) Dengan Status Gizi Baduta Di Kabupaten Cirebon. Amerta Nutrition. 4, 155 (2020).

14. Anak, K. P. P. Dan P. Profil Perempuan Indonesia. Profil Perempuan Indonesia (2019).

15. Salman, Arbie, F. Y. \& Humolungo, Y. Hubungan Pengetahuan Gizi Ibu Dengan Kejadian Stunting. Health Nutrition Journal. 3, 42-53 (2017).

16. Perumal, N. et al. Health and nutrition knowledge, attitudes and practices of pregnant women attending and not-attending ANC clinics in Western Kenya: A cross-sectional analysis. BMC Pregnancy Childbirth 13, 1-12 (2013).

17. Wulandari, R. C. \& Muniroh, L. Hubungan Tingkat Kecukupan Gizi, Tingkat Pengetahuan Ibu, dan Tinggi Badan Orangtua dengan Stunting di Wilayah Kerja Puskesmas Tambak Wedi Surabaya. Amerta Nutr. 4, 95 (2020).

18. Rachman, B. N., Mustika, I. G. \& Kusumawati, I. G. A. W. Faktor yang berhubungan dengan perilaku konsumsi buah dan sayur siswa SMP di Denpasar. J. Gizi Indones. (The Indones. J. Nutr. 6, 9-16 (2017).

19. Saputri, R., Lestari, L. A. \& Susilo, J. Pola konsumsi pangan dan tingkat ketahanan pangan rumah tangga di Kabupaten Kampar Provinsi Riau. J. Gizi Klin. Indones. 12, 123 (2016).

20. Setyawati, V. A. V. \& Rimawati, E. Pola Konsumsi Fast Food Dan Serat Sebagai Faktor Gizi Lebih Pada Remaja. Unnes Journal Public Health. 5, 275 (2016).

21. Angraini, D. I. Perilaku Konsumsi Makanan Berisiko Berhubungan dengan Status Gizi pada Pasien Poliklinik Universitas Lampung Behavioral
Risk Food Consumption Associated With Nutritional Status in Patients on University of Lampung Clinic. Kedokteran Komunitas. 26-30 (2015).

22. Marvin-Dowle, K., Kilner, K., Burley, V. \& Soltani, $H$. Differences in dietary pattern by maternal age in the born in bradford cohort: A comparative analysis. PLoS One 13, 1-14 (2018).

23. Negeri, D., Manado, K., Wowor, P., Engkeng, S. \& Kalesaran, A. F. C. Faktor-Faktor Yang Berhubungan Dengan Perilaku Konsumsi Jajanan Pada Pelajar Di Sekolah Dasar Negeri 16 Dan Sekolah Dasar Negeri 120 Kota Manado. Kesmas 7, (2018).

24. Nurdiyanti, H. \& Wahyuningtyas. Dengan Perilaku Kebiasaan Jajan Siswa Mi Nurul Islamiyah Tahun 2017. Jurnal Medika Respati 14, 321-330 (2019).

25. Ramadhani, D. T. \& Hidayati, L. Faktor-Faktor yang Mempengaruhi Konsumsi Sayur dan Buah pada Remaja Putri SMPN 3 Surakarta. Seminar Nasional Gizi 45-58 (2017).

26. Diddana, T. Z. Factors associated with dietary practice and nutritional status of pregnant women in Dessie town, northeastern Ethiopia: $\mathrm{A}$ community-based cross-sectional study. BMC Pregnancy Childbirth 19, 1-10 (2019).

27. Rabbaniyah, F. \& Nadjib, M. Analisis Sosial Ekonomi dalam Pemanfaatan Fasilitas Kesehatan untuk Berobat Jalan di Provinsi Jawa Barat: Analisis Data Susenas Tahun 2017 S. Jurnal Media Kesehatan Masyarakat Indonesia. 15, 7380 (2019). 